\title{
Calcineurin inhibitor
}

National Cancer Institute

\section{Source}

National Cancer Institute. Calcineurin inhibitor. NCI Thesaurus. Code C146638.

Any agent that inhibits calcineurin (protein phosphatase 3; PPP3), a serine/threonine protein phosphatase dependent on calcium and calmodulin, with immunosuppressant activity. Inhibition of calcineurin prevents dephosphorylation of the transcription factor nuclear factor of activated T-cells, cytoplasmic (NFATC), which prevents its translocation to the nucleus and the subsequent induction of the expression of interleukin-2 (IL-2). This prevents IL-2-mediated proliferation and activation of T-cells, and T-lymphocytemediated immune responses. 